CURRENT RESEARCH JOURNAL OF PHILOLOGICAL SCIENCES

(ISSN -2767-3758)

VOLUME 03 ISSUE 01 Pages: 120-126

SJIF IMPACT FACTOR (2021: 5 . 823)

OCLC - 1242423883 METADATA IF - 6.925

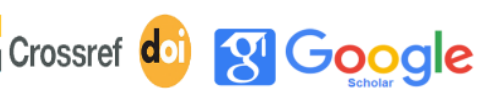

\%

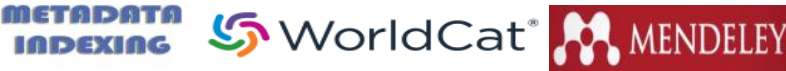

Publisher: Master Journals

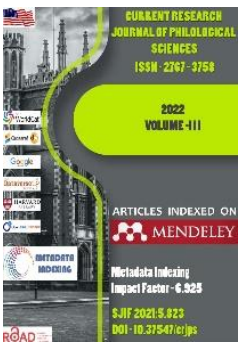

Journal Website: https://masterjournals. com/index.php/crips

Copyright: Original content from this work may be used under the terms of the creative commons attributes 4.0 licence.
Research Article

\section{THE AMALGAMATION OF ENGLISH LANGUAGE FOR CE STUDENTS THROUGH NEEDS ANALYSIS}

\author{
Submission Date: January 11, 2022, Accepted Date: January 21, 2022, \\ Published Date: January 31, 2022 \\ Crossref doi: https://doi.org/10.37547/philological-crjps-03-01-21
}

\section{Dilobarkhon Azimova}

Kokand University, Uzbekistan

\title{
ABSTRACT
}

With regard to the acceleration of English language learning in the world, every aspect of life is required to acquire basic knowledge of English irrespective of their scope. Subjects, courses at Higher Educational Institutes are willingly integrating language learning as part of their compulsory program. However, to amalgamate this process into action, some priorities should be taken into serious consideration such as needs analysis which reveals students basic wants of the language.

\section{KEYWORDS}

Needs analysis, questionnaire, academic writing, CLT, deductive approach, interview, IT.

\section{INTRODUCTION}

The needs analysis is the primary stage of designing the ESP course. According to Hyland (2006), needs analysis is an umbrella term which combines the techniques for collecting information and evaluating them for the establishment of effective methods for the course. Needs refers to what the learners "know, do not know and want to know". The process of the needs analysis can be conducted in different ways.

This paper is aimed to demonstrate the process and findings of needs analysis among 20 students at Kokand University who study at CE (Computer Engineering). In order to identify the learners' 


\section{CURRENT RESEARCH JOURNAL OF PHILOLOGICAL SCIENCES}

(ISSN -2767-3758)

VOLUME 03 ISSUE 01 Pages: 120-126

SJIF IMPACT FACTOR (2021: 5. 823)

OCLC - 1242423883 METADATA IF - 6.925

\section{Crossref

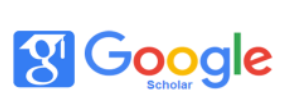

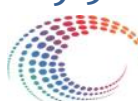

metapata

5. WorldCat ${ }^{*}$ भ̂े MENDELEY

Publisher: Master Journals

"needs"," wants" and "lacks" which were stated by Hutchinson \& Waters (1987) as the key components of the assessment, I interviewed the participants online via the Zoom platform. Moreover, the participants completed the questionnaire which was sent to their emails. Based on their responses we could identify that the target students need to comprehend authentic IT texts and write a research project at the end of the term.

The data collection helped us to set realistic goals, to design the content of the course and to determine the types of assessments. Brindley (1989) argued that a great focus on needs analysis leads to design "negotiated" syllabus, which includes not only what should be learned but also drawing attention to the students' cognitive abilities and their preference. The initial plan of needs analysis is designed for an ESP course students specializing CE at Kokand University. The target learners are freshmen, Uzbek and Russian students aged 18-19. There are 18-20 students in each group and their proficiency level is between 5.0-5.5 IELTS band scores. The target learners' needs are in selecting technical vocabulary, topics related to IT and writing business letters and reports. At the end of the course the students will be able to:

- Communicate in the field of CE effectively;

- Use special vocabulary both in spoken and written forms;

- Comprehend technical texts;

- Improve the academic writing style;

It is essential to conduct a needs analysis, which will help to identify learners' needs and lacks in order to develop an ESP course for target learners. According to Long (2005), inductive and deductive ways of needs analysis can be used to find out the learners' needs. However, Lincoln and Guba (1985) suggest utilizing unstructured interviews as they help to find out what they are not aware of learners. Relying on these suggestions, we have decided to implement both deductive and inductive methods for gathering data and firstly, conduct unstructured interviews, secondly a questionnaire and finally a test that helps us to recognize the needs of the students. It is challenging to predict the similarity between the needs and wants of the students as sometimes the learners do not see the necessity to develop a particular skill. As Flowerdew (2010) mentioned about discrepancies between the learners' needs and wants that were identified after his needs analysis, it is evident that we may have a similar situation. We are expecting to identify which skills are very essential for them and need-to-have aspects such as expressions and terminology used in IT specialty, good comprehension of software descriptions and manuals which are all written in technical English for better understanding globally. In terms of good-to-have aspects, they are anticipated to develop presentation skills, understanding lectures and acquiring the competence of comprehensible discussions

\section{METHODS}

To investigate IT students' needs in learning the English language, a deductive method was applied which contained 3 stages (unstructured interviews, a questionnaire and a writing test). Snieder claims "the deductive approach follows the path of logic most closely. The reasoning starts with a theory and leads to a new hypothesis. This hypothesis is put to the test by confronting it with observations that either leads to a confirmation or a rejection of the hypothesis" (2009, p. 16). Moreover, quantitative and qualitative data were provided to demonstrate learners' preference in language learning. First, the learners were invited to the interview where they were given 
CURRENT RESEARCH JOURNAL OF PHILOLOGICAL SCIENCES

(ISSN -2767-3758)

VOLUME 03 ISSUE 01 Pages: 120-126

SJIF IMPACT FACTOR (2021: 5. 823)

OCLC - 1242423883 METADATA IF - 6.925

\section{Crossref dol gु Google}

\section{DATA COLLECTION}

questions in sequence based on their answers in order

Needs analysis is conducted and the learner needs, University. The researchers used the Zoom platform lacks and wants are identified with the assistance of to talk with 20 participants since they were unable to present in the interview. The next tool, a questionnaire survey was used to gather more detailed information. In the last stage, students were asked to write a report in order to check their knowledge on writing strategies and expressions in their specialty. interview questions, questionnaire and a writing task (Appendix A), which are provided to the target learners. Firstly, the target learners asked to answer the interview questions to identify their needs. Secondly, the learners filled in the questionnaire which helped to identify their wants. The following charts demonstrate the wants of the learners:

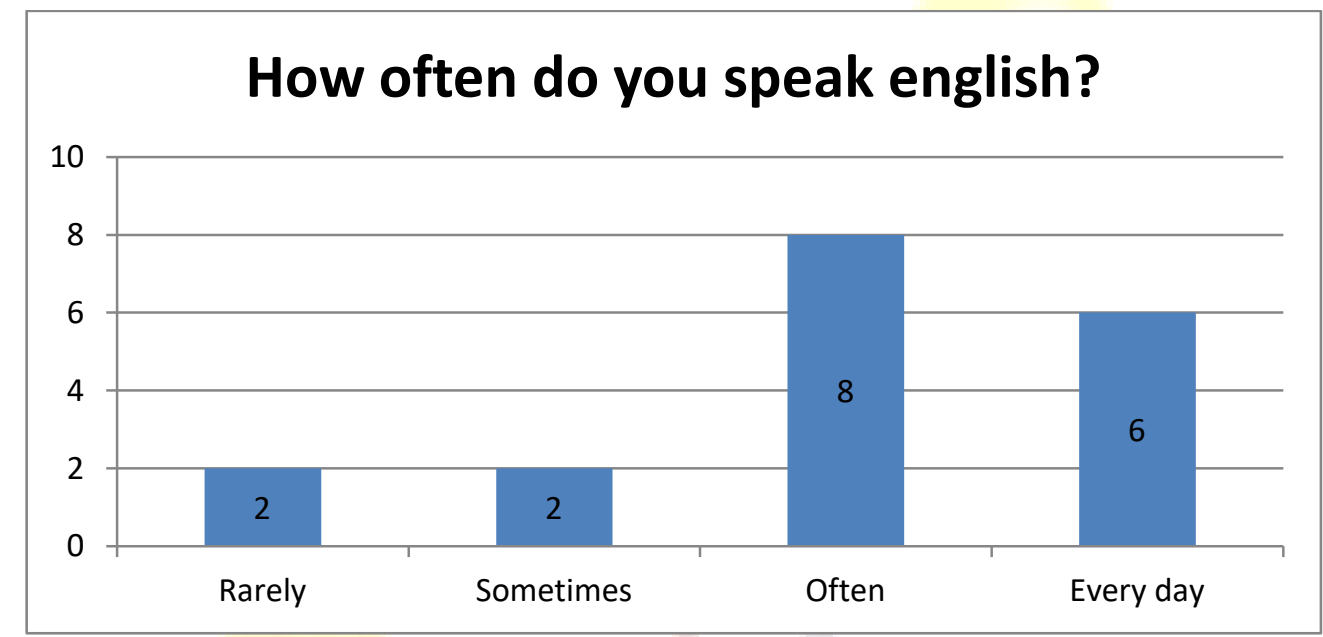


CURRENT RESEARCH JOURNAL OF PHILOLOGICAL SCIENCES

(ISSN -2767-3758)

VOLUME 03 ISSUE 01 Pages: 120-126

SJIF IMPACT FACTOR (2021: 5. 823)

OCLC - 1242423883 METADATA IF -6.925

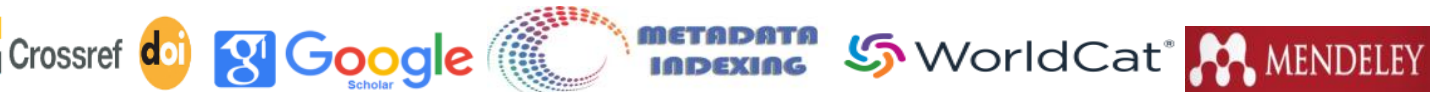

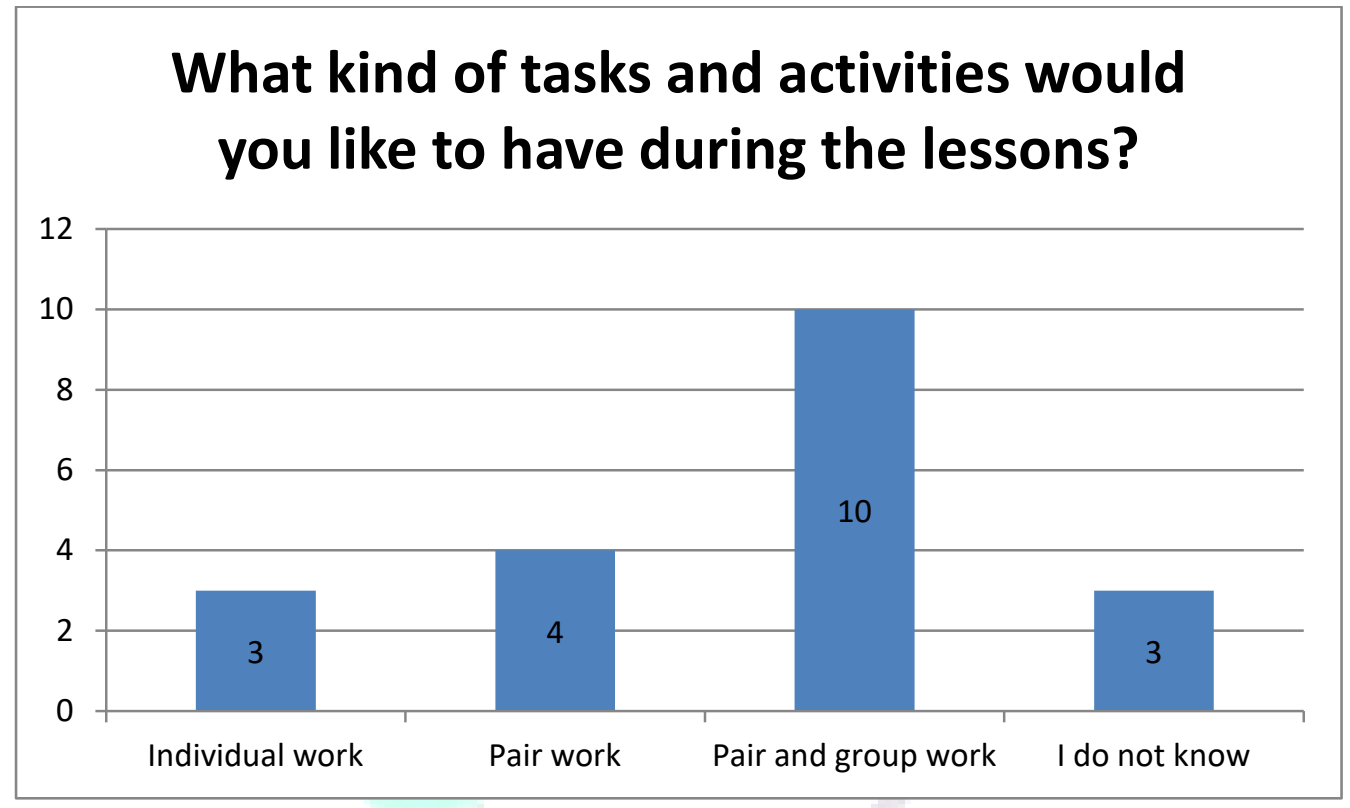

What would you like to study in this course?

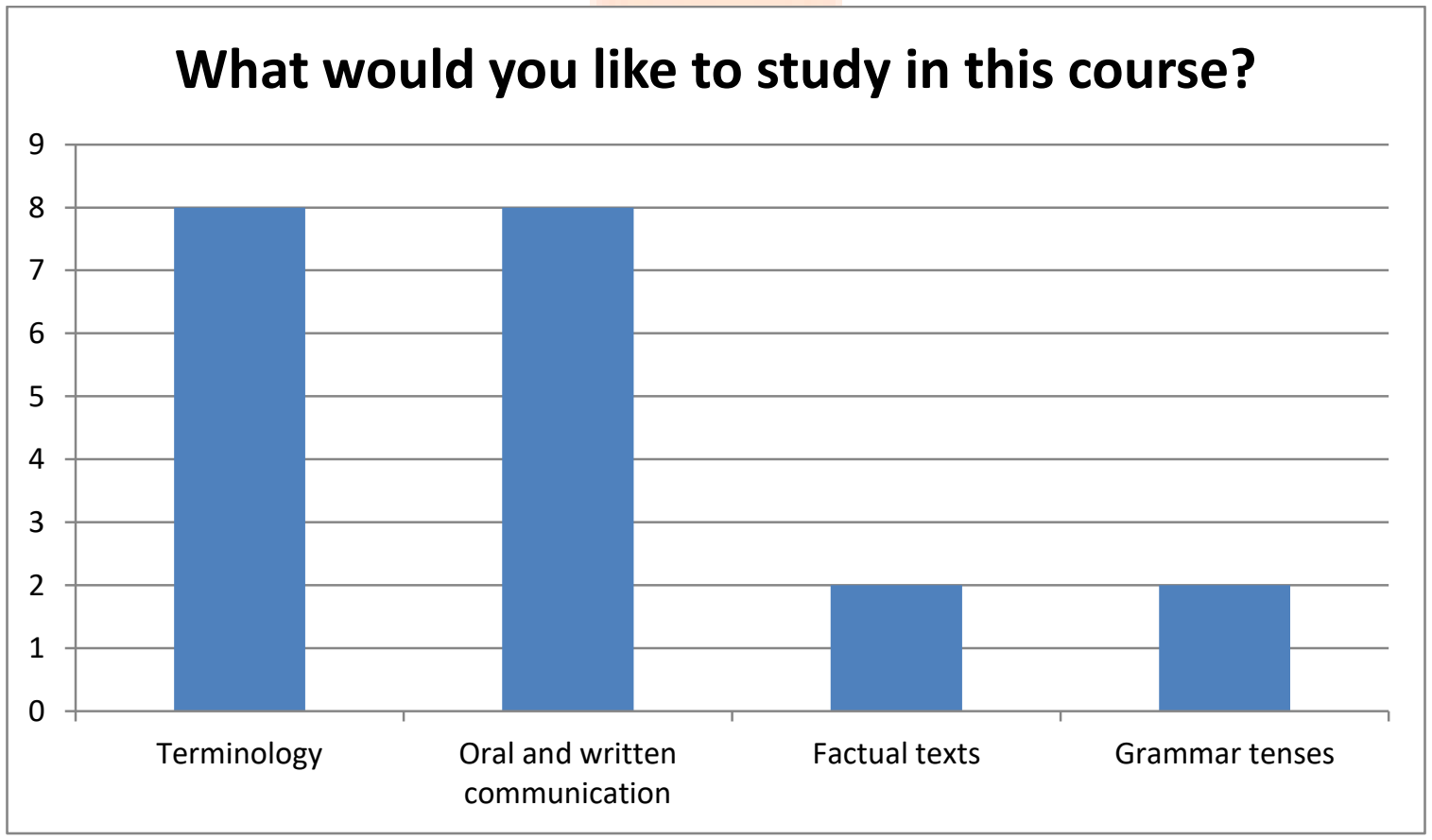


CURRENT RESEARCH JOURNAL OF PHILOLOGICAL SCIENCES

(ISSN -2767-3758)

VOLUME 03 ISSUE 01 Pages: 120-126

SJIF IMPACT FACTOR (2021: 5 . 823)

OCLC - 1242423883 METADATA IF - 6.925

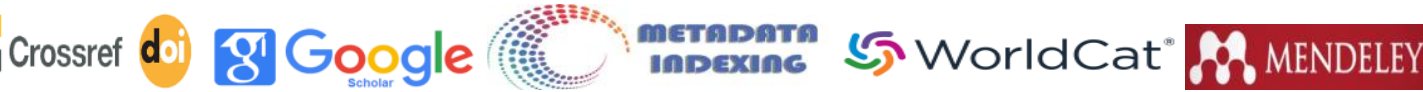

Publisher: Master Journals

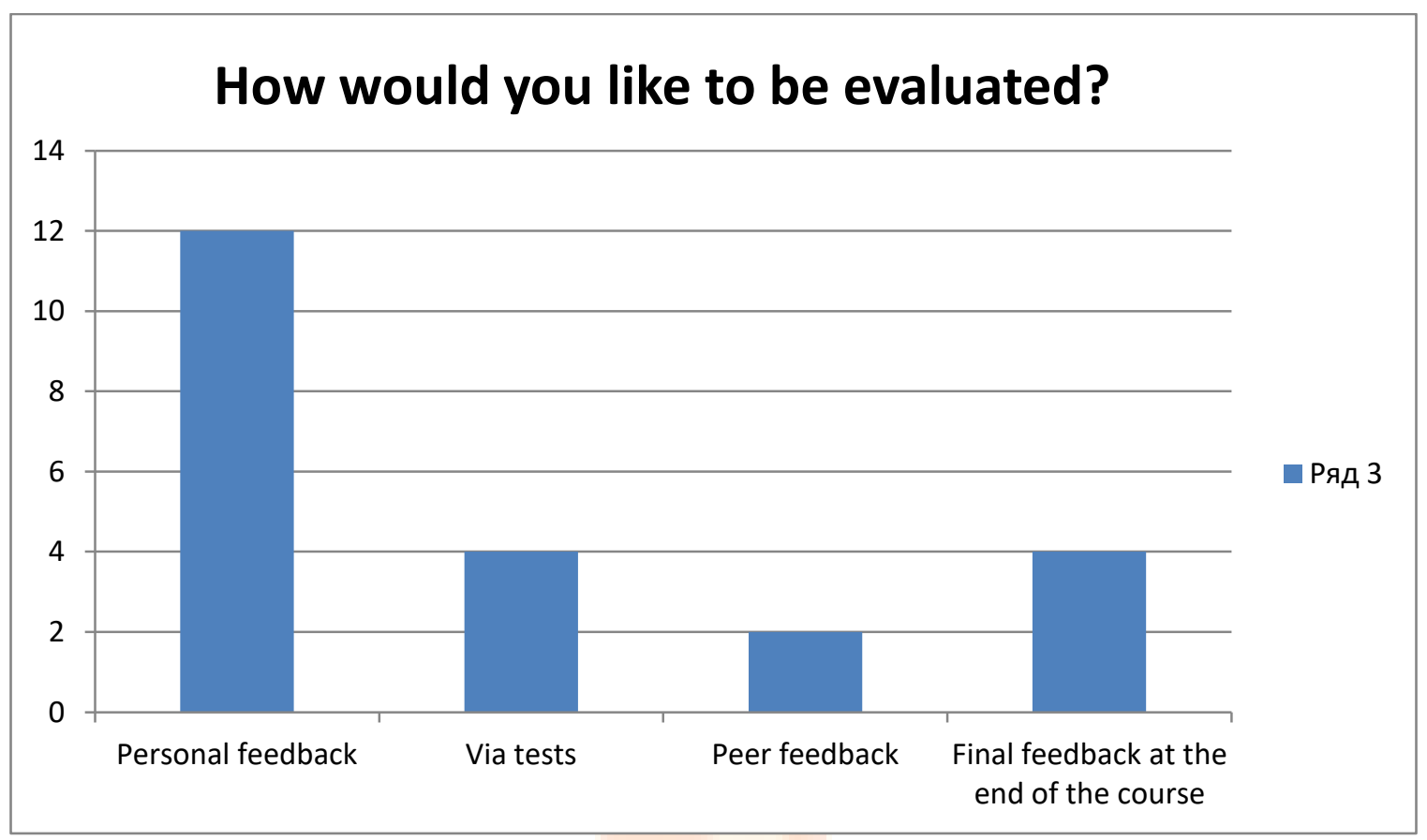

Finally, the target learners were asked to complete the writing task to find out about their lacks.

\section{RESULTS}

The methods of data collection have revealed needs, wants and lacks of target learners. To illustrate, conducted interviews through the Zoom platform helped to identify their language needs that participants made it clear that they did not have ESP classes before and looking forward to having one. The minority of students mentioned that they attended General English classes and their existing level is PreIntermediate while others learned English just for pleasure and dealt with speaking mostly. They have intrinsic motivation to learn English and stated that having ESP class two or three times a week is enough. As most of them agreed, learning the English language will help them to develop professionally bringing multiple opportunities in the job market in the upcoming years. Besides, they need both production and comprehension skills to be improved if possible. Accordingly, when they were asked about language difficulties, nearly all claimed that they find it difficult to produce topic-related vocabulary, sticking general words they know. The majority told that they have a strong desire to show their intentions in writing as well while the others find understanding others' speech quite challenging.

With respect to the questionnaire, it was clarified that most of them prefer speaking in English more often and utilize it in everyday life; this method was indicating their existing wants from the expected course. Visual learners account for most of the learners (12 students) which shows that presentations, various illustrations and handouts can be applied to teach these students. Importantly, the 


\section{CURRENT RESEARCH JOURNAL OF PHILOLOGICAL SCIENCES}

(ISSN -2767-3758)

VOLUME 03 ISSUE 01 Pages: 120-126

SJIF IMPACT FACTOR (2021: 5. 823)

OCLC - 1242423883 METADATA IF - 6.925

group works, pair works are found to be more appealing for ten of the participants and it can ease the work of teachers since these forms of activities enhance collaboration skills. Coming to language skills, they want to have oral and written communication to be improved together with some terminology. In terms of evaluation, the majority of learners (12 students) opted for individual feedback rather than having corrections during the lesson or final feedback at the end of the course.

The writing task helped to identify participants' lacks in language usage. It is visible that they have difficulty in utilizing specific, topic-related vocabulary and transitional devices in sentences. Regardless of some grammatical mistakes, other parts of the essays were quite acceptable. Relying on this survey, the ESP course can integrate some formal instructions which target to teach grammatical structures involving transitional devices, connectors. Also, vocabulary should be prioritized and drilled in every lesson in accordance with topics.

These findings can be a strong basis in the preparation of materials for the ESP course. Taking learners' needs, wants and lacks into account can benefit both teachers and students simultaneously providing mutual understanding between these two actors in education.

\section{CONCLUSION}

The current needs analysis was the small scale research to identify the main "needs, wants, and lacks" of the target learners for the planning effective ESP course for CE students. In conclusion, the results of the interview, questionnaire and writing task clearly illustrated the students' both professional needs and the needs of the language skills. Obtaining all necessary data about participants, we can determine the objectives of the course, choose appropriate materials, methods and design curriculum content that enhance the participants' motivation for achieving success in the ESP course. The intended course will last ten months and be organized twice a week, each lesson covering 80 minutes.

Sessions will focus on listening, speaking, reading and writing skills since learners should be able to understand articles related to their major and they are required to take notes during the lectures, write emails and reports. CLT (Communicative Language Teaching) approach will be implemented into teaching in order to organize interactive lessons with both peers and the instructor which is based on authentic materials; furthermore, through this method, students will be motivated to use the language inside and outside of the class. The university provides needed materials and coursebooks; moreover, students will have open access to online libraries.

\section{REFERNCES}

1. Brindley, G. (1989) The role of needs analysis in adult ESL program design. In R. K.

2. Flowerdew. L. (2010). Devising and implementing a business proposal module: Constraints and compromises. English for Specific Purposes 29: 27-46

3. Hyland, K. ( 2006 ) English for Academic Purposes. London: Routledge.

4. Hutchinson, T. and Waters, A. (1987) English for Specific Purposes. A Learning- Centred Approach. Cambridge: Cambridge University Press.

5. Snieder, R. \& Larner, K. (2009) The Art of Being a Scientist: A Guide for Graduate Students and their Mentors. Cambridge University Press, (p.16) 
CURRENT RESEARCH JOURNAL OF PHILOLOGICAL SCIENCES

(ISSN -2767-3758)

VOLUME 03 ISSUE 01 Pages: 120-126

SJIF IMPACT FACTOR (2021: 5. 823)

OCLC - 1242423883 METADATA IF - 6.925

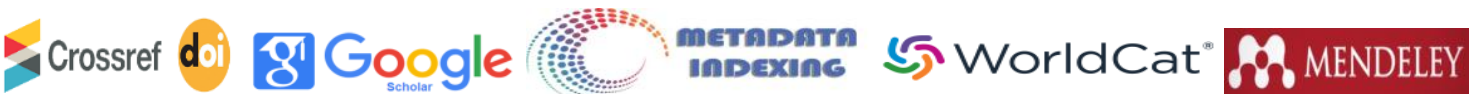

Publisher: Master Journals

6. Lincoln, Y. and Guba, E. (1985). Naturalistic Enquiry. Newbury Park, CA: Sage.
7. Long, M. (2005). Second Language Needs Analysis. Cambridge: Cambridge University Press 